\title{
Landscape Change Associated with the Upper Scenic Drive Landslide, La Honda, California, January 10-June 28, 2017
}

By Alexandra J. Pickering, Carol S. Prentice, and Stephen B. DeLong

Pamphlet to accompany

Open-File Report 2019-1024 


\title{
U.S. Department of the Interior \\ DAVID BERNHARDT, Secretary
}

\author{
U.S. Geological Survey \\ James F. Reilly II, Director
}

\author{
U.S. Geological Survey, Reston, Virginia: 2019
}

For more information on the USGS - the Federal source for science about the Earth, its natural and living resources, natural hazards, and the environment-visit http://www.usgs.gov/ or call 1-888-ASK-USGS (1-888-275-8747).

For an overview of USGS information products, including maps, imagery, and publications, visit http://store.usgs.gov/.

Any use of trade, firm, or product names is for descriptive purposes only and does not imply endorsement by the U.S. Government.

Although this information product, for the most part, is in the public domain, it also may contain copyrighted materials as noted in the text. Permission to reproduce copyrighted items must be secured from the copyright owner.

Suggested citation:

Pickering, A.J., Prentice, C.S., and DeLong, S.B., 2019, Landscape change associated with the upper Scenic Drive landslide, La Honda, California, January 10-June 28, 2017: U.S. Geological Survey Open-File Report 2019-1024, 17 p., 1 sheet, scale 1:400, https://doi.org/10.3133/ofr20191024.

ISSN 2331-1258 (online) 


\section{Contents}

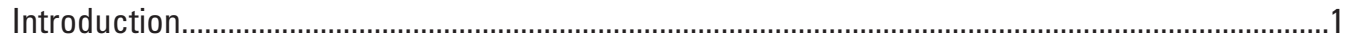

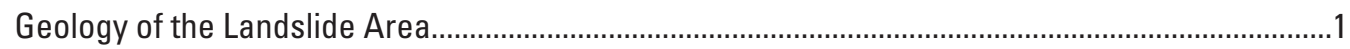

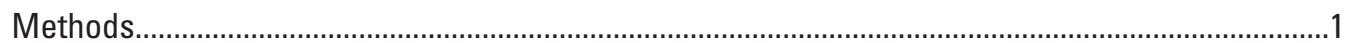

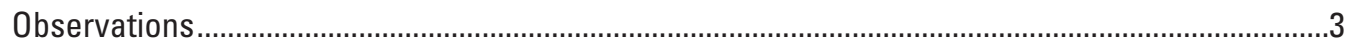

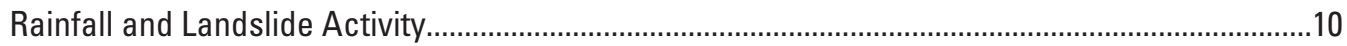

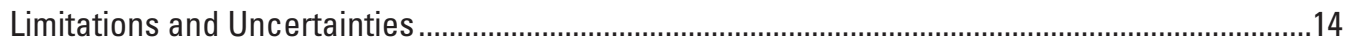

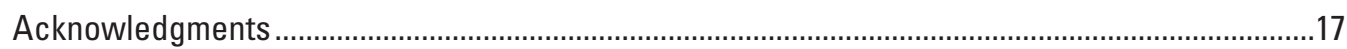

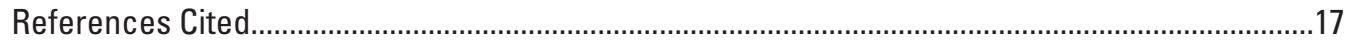

\section{Figures}

1. Map of La Honda, California, showing location of Scenic Drive landslides and rain gauge LAH. .2

2. Bare-earth shaded-relief image of upper Scenic Drive landslide and surrounding area. Figure is on map sheet; caption included here for continuity.. map sheet

3. Same bare-earth shaded-relief image as figure 2, showing features of upper Scenic Drive landslide mapped in field. Figure is on map sheet; caption included here for continuity map sheet

4. Schematic block diagram (modified from Varnes, 1978), showing generalized characteristics of deep-seated landslides.

5. Photographs to north-northeast of upper part of Scenic Drive, showing development of right flank upper Scenic Drive landslide (USDL), which crosses roadway

6. Photographs to east taken in backyard of home at 345 Scenic Drive, showing development of graben along right flank of upper Scenic Drive landslide.

7. Oblique aerial photographs of Scenic Drive area, showing features of upper Scenic Drive landslide

8. Oblique aerial photographs to northeast, showing localized failure along toe of upper Scenic Drive landslide

9. Oblique aerial photographs of upper Scenic Drive area, showing features of upper Scenic Drive landslide

10. Schematic map showing boundaries of previous $(1998,2005,2006)$ Scenic Drive landslides, compared to that of 2017 upper Scenic Drive landslide.

11. Slope-shade map of upper Scenic Drive landslide, showing real-time kinematic global positioning system and terrestrial laser scanner survey points. Also shown are horizontal displacement vectors that indicate magnitude and direction of movement from January 27-Februrary 23, 2017.

12. Shaded-relief map of upper Scenic Drive landslide, showing magnitudes and directions of total horizontal displacement between 2016 and 2017, as measured by optical image correlation.

13. Maps showing changes in elevation within upper Scenic Drive landslide and in surrounding area

14. Contour map and topographic profiles of upper Scenic Drive landslide and surrounding area

15. Plot showing cumulative rainfall for rainfall year 2016-2017, at La Honda, Calif., from rain gauge $\mathrm{LAH}$

16. Plot showing cumulative rainfall for rainfall year 2016-2017 and four preceding rainfall years, at La Honda, Calif., from rain gauge LAH 


\section{Table}

1. Horizontal and vertical displacement values and displacement azimuths for seven informally designated monuments within the 2017 upper Scenic Drive landslide ..........11 


\title{
Landscape Change Associated with the Upper Scenic Drive Landslide, La Honda, California, January 10-June 28, 2017
}

\author{
By Alexandra J. Pickering, Carol S. Prentice, and Stephen B. DeLong
}

\section{Introduction}

La Honda, California, is a small town in unincorporated San Mateo County, located on the west edge of the San Francisco Peninsula in the Santa Cruz Mountains, between San Francisco and San Jose (fig. 1). The Scenic Drive area of La Honda has experienced several past episodes of landslide motion (as a group, referred to herein as SDL), which were documented in 1998 (Jayko and others, 1998), 2005 (Wells and others, 2005), and 2006 (Wells and others, 2006). This report documents movement of the upper Scenic Drive landslide (referred to herein as the USDL) that occurred between January 10 and June 28, 2017. Figure 2 (on map sheet) provides a snapshot of the 2017 USDL, as imaged from high-resolution terrestrial laser scanner (TLS) survey data (also referred to as terrestrial lidar) we collected January 27-28, 2017; figure 3 (on map sheet) shows the landforms we mapped that are associated with landslide motion (terminology from Varnes, 1978; see also, fig. 4), using a bare-earth TLS shaded-relief base map and supplemented with photographs (figs. 5, 6, 7, 8, 9) taken between January 11 and 31, 2017, to illustrate the development of selected landslide features. The purpose of this report is to make available maps constructed from three-dimensional TLS data and photographs that show the landslide morphology of the 2017 USDL. The scope of this report is limited to USDL motion that occurred between January 10 and June 28, 2017. A geotechnical report by Buckley and Reid (2016) documented minor motion of the USDL that occurred in 2016, prior to any of our measurements.

\section{Geology of the Landslide Area}

The La Honda area is part of a probable prehistoric landslide complex mapped by Brabb and Pampeyan (1972). The area is underlain by the Purisima Formation, a late Miocene and Pliocene marine sedimentary sequence dominantly composed of interbedded sandstone and mudstone that dips gently to the southwest (Brabb and others, 1998). The Purisima Formation unconformably overlies the Mindego Basalt of Oligocene to Miocene age, a submarine volcanic unit that dips more steeply than the Purisima Formation. The slip surfaces for both the SDL and the 2017 USDL are within the Purisima Formation, above the contact with the Mindego Basalt (Upp, 1998; Wells and others, 2005; Buckley and Reid, 2016). Buckley and Reid (2016) observed that the 2017 USDL slip surface is a developed failure surface that consists of clay gouge, which likely represents the basal surface of a prehistoric landslide that has been recently reactivated. In both cases, the landslide slip surface typically is approximately 8 to $10 \mathrm{~m}$ below the ground surface (Wells and others, 2006; Buckley and Reid, 2016). The 2017 USDL is both adjacent to, and upslope of, earlier SDL episodes (fig. 10). The 2017 USDL slip surface is distinct from, and not connected to, the 1998-2005-2006 SDL slip surface, and, therefore, the 2017 USDL is a different (and separate) landslide from the older SDLs. Whether or not the SDLs and the 2017 USDL share a common ancient landslide slip surface at depth is beyond the scope of this report (determining this would require a substantial drilling project). A significant effort to stabilize the lower SDL that was completed by San Mateo County in 2011 appears to be successful. Our surveys show that no measurable displacement has occurred on this landslide since the stabilization project was completed. We note that the south boundary of the 2017 USDL is nearly coincident with the northernmost tie-back anchor emplaced under upper Scenic Drive as part of the San Mateo County stabilization project (fig. 3 [on map sheet]; see also, fig. 9C).

\section{Methods}

On January 27-28, 2017, we collected threedimensional lidar data of the 2017 USDL, using a Riegl VZ400 terrestrial laser scanner (TLS) integrated with a Leica GS15 real-time kinematic (RTK) global positioning system (GPS). The TLS scans produced point clouds that we aligned, filtered, georeferenced, classified by height, and gridded, using the triangulated irregular network (TIN) and inverse distance to a power (IDP) methods, to generate 


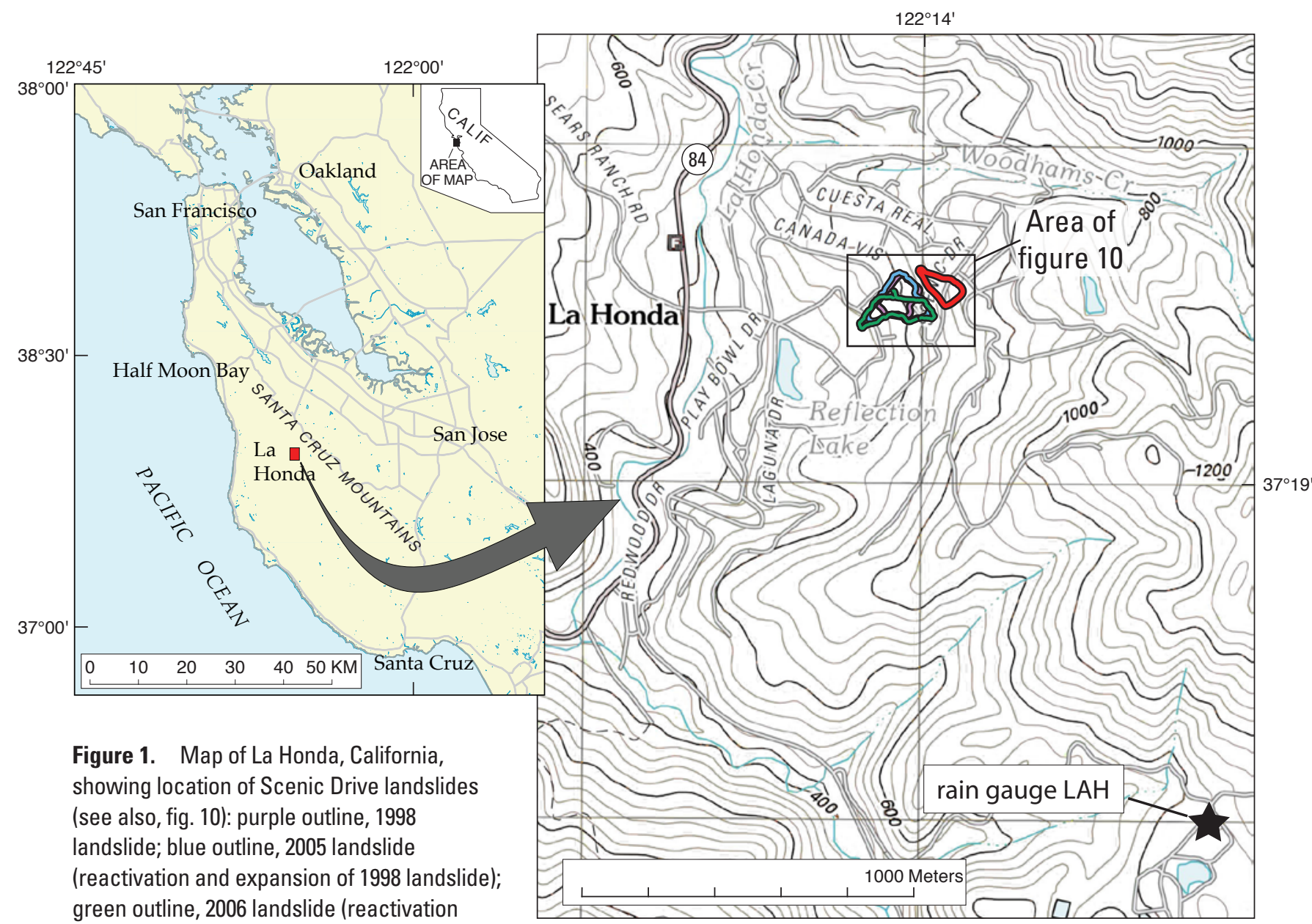
and expansion of 2005 landslide); red outline, 2017 upper Scenic Drive landslide. Star shows location of rain gauge LAH (see figs. 14, 15). Topographic base map from La Honda U.S. Geological Survey 1:24,000-scale quadrangle.

Figure 2 (on map sheet). Bare-earth shaded-relief image of 2017 upper Scenic Drive landslide (USDL) and surrounding area, constructed from terrestrial laser scanner (TLS) survey data (also referred to as terrestrial lidar) collected January 27-28, 2017. Faceted areas (sharp-angled shapes in image) are data-collection artifacts containing no or few data points. Scale, 1:400; projection, NAD83 UTM zone 10N. TLS survey data from Pickering and others (2018). Figure is on map sheet; caption included here for continuity.

Figure 3 (on map sheet). Same bare-earth shaded-relief image as figure 2 (constructed from terrestrial laser scanner [TLS] survey data), showing features of 2017 upper Scenic Drive landslide (USDL) mapped in field. Numbers in white squares refer to structures within image area discussed in figures 5, 6, 7, 8, 9, and 13. Figure numbers point out general locations where photographs in figures 4, 5, and 7 were taken. Scale, 1:400; projection, NAD83 UTM zone $10 \mathrm{~N}$. TLS survey data from Pickering and others (2018). Figure is on map sheet; caption included here for continuity. several 5-cm-resolution digital elevation models (DEMs). The same procedure also was used for lidar data we had collected on January 15, 2016, on lower Scenic Drive while monitoring the stability of the previous SDLs, although the two datasets only partly overlap. Classified point clouds and DEMs of the 2016 and 2017 data are available (Pickering and others, 2018). Using points classified as ground or building, we produced 5-cm-resolution DEMs from which we constructed bare-earth shaded-relief images (figs. 2, 3, on map sheet) and slope-shade maps (figs. 11, 12) of the 2017 USDL. We differenced the 2017 TLS data with 1-m-resolution airborne-lidar data collected by San Mateo County in 2005 to determine total vertical elevation changes within the 2017 USDL (fig. 13A). We also differenced the 2017 TLS data with the 2016 TLS data where the two datasets overlap (fig. 13B). Lastly, we created a 0.5-m-resolution contour map and associated topographic profiles (fig. 14). In addition to the TLS surveys, we used 


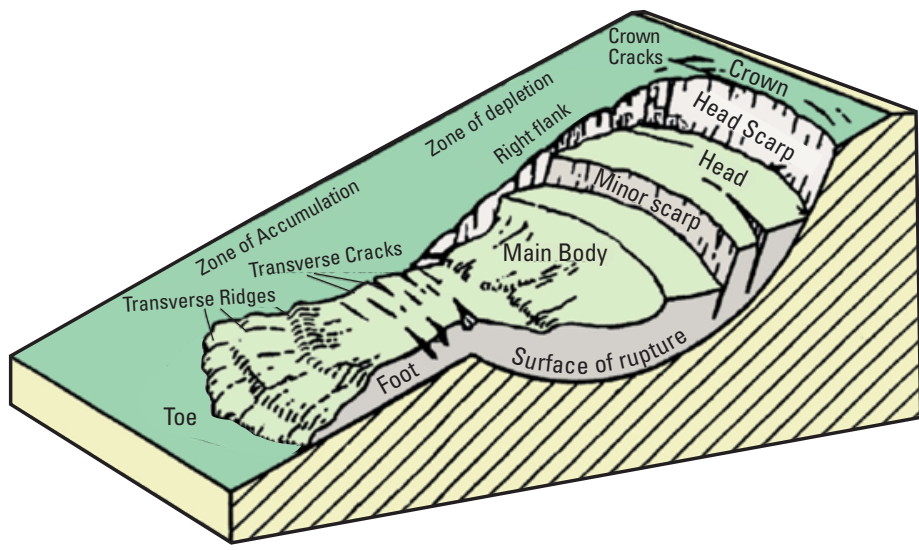

Figure 4. Schematic block diagram (modified from Varnes, 1978) showing generalized characteristics of deep-seated landslides.

RTK GPS for eight repeated surveys of formal and informal monuments collected between January 27 and June 28, 2017, to monitor slip direction (fig. 11) and magnitude (table 1; note that, although all 58 monuments depicted in figure 10 were repeatedly surveyed, only those that moved horizontally more than $2 \mathrm{~cm}$ between January 27 and February 23, 2017, are listed in table 1). Subsequent measurements showed no motion within the measurement error of about $2 \mathrm{~cm}$ horizontally and about $3 \mathrm{~cm}$ vertically. We set up a local base station outside the boundary of the 2017 USDL and kinematically surveyed 16 nails installed along Scenic Drive and also along Fir View and Woodland Vista roads; we set up five of these nails previously and surveyed them in 2016 as part of the 2016 TLS survey. In addition, we surveyed 16 lane reflectors along Scenic Drive, as well as 26 temporary aerial survey targets throughout the vicinity of the USDL (fig. 11), to monitor stability of past SDLs and movement of the 2017 USDL. Note that the GPS surveys began 17 days after landslide movement was first detected, capturing only the end of landslide movement. We measured apparent total horizontal deformation vectors using optical imagery acquired July 19, 2016, and May 17, 2017, by the DigitalGlobe WorldView-2 satellite. The images were coregistered using ESRI's ArcGIS, using objects that were visible in both images but were away from the landslide. Displacements were measured using the Cosi-CORR image correlation software (Leprince and others, 2007). Apparent spurious displacements away from the landslide indicate errors (at the decimeter level) due to coregistration, image noise, and differences in object distortion from satellite nadir angle.

\section{Observations}

Movement of the USDL in 2017 began on or just before January 10, 2017, as was reported by the residents of 345 Scenic Drive (structure \#3; see fig. 3 [on map sheet]), who noticed new cracks in their driveway and garage floor. Early in the morning of January 11, 2017, the residents observed a water-line break in front of their home on upper Scenic Drive, caused by landslide motion; they notified authorities, and the water line was shut off at around 3 a.m. Figure 5 , which shows two photographs taken (on January 11 and 25, 2017) of the road in front of 345 Scenic Drive, illustrates the development of the northern lateral boundary (right flank) of the landslide. Between January 20 and 23, 2017, additional
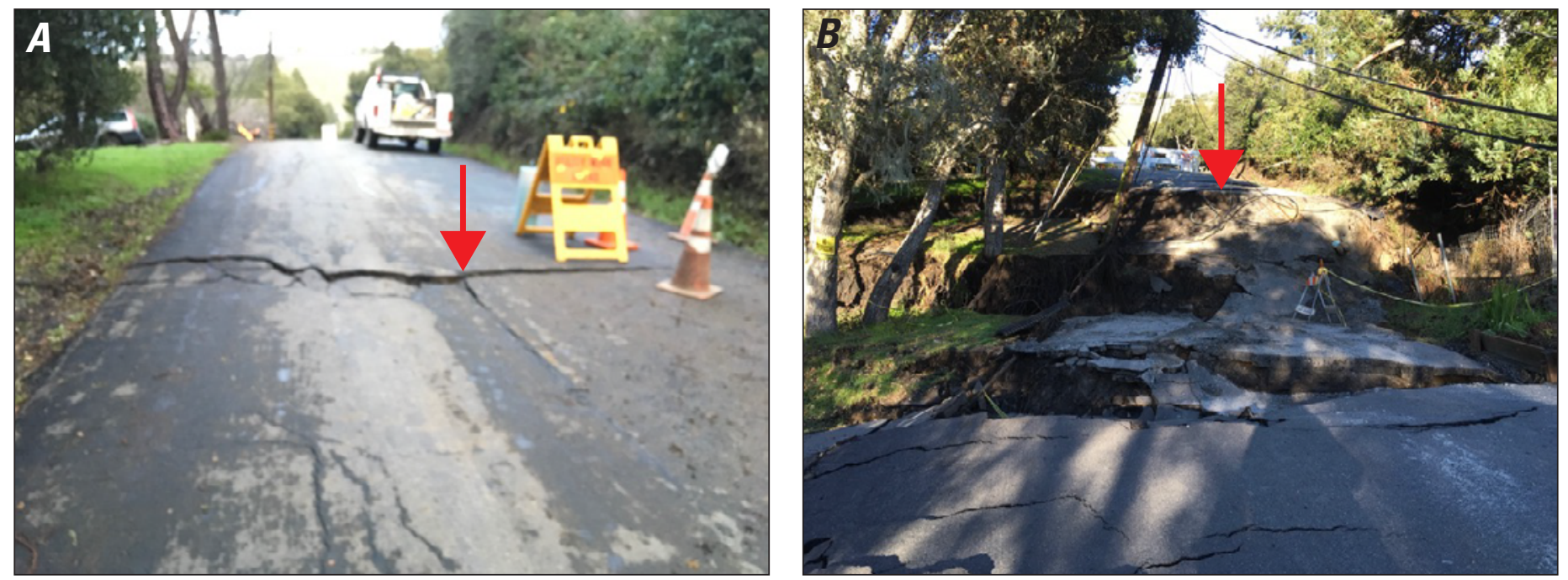

Figure 5. Photographs to north-northeast of upper part of Scenic Drive, showing development of right flank (northern margin) of 2017 upper Scenic Drive landslide (USDL), which crosses roadway. Red arrow points to same location in both photographs. Photographs by Carol Prentice. See figure 3 (on map sheet) for location. $A$, Photograph taken on January 11, 2017, showing initiation of landslide movement. Note that this lowresolution image is only photograph available that shows early landslide movement. $B$, Photograph taken on January 25,2017 , showing advanced movement (4-m vertical displacement) along right flank of 2017 USDL. Note white barricade across road above right flank. 
landslide motion occurred as a result of storms that brought additional rainfall to the already wetted region. Figure 6 illustrates the development of a graben along the northern lateral boundary of the slide behind (west of) the residence at 345 Scenic Drive between January 11 and 24, 2017.

The pond that formed within the graben was intentionally breached to provide drainage of the area. Aerial views (figs. $7,8,9)$ show development of landslide features between January 11 and 31, 2017.

Figure 3 (on map sheet) shows a map of landslide features as they appeared January 27 and 28, 2017. The 2017 USDL is roughly triangular in shape, measuring approximately 150 by $80 \mathrm{~m}$, and covering about $8,000 \mathrm{~m}^{2}$. The headscarp extends along the northeastern part of the landslide for approximately $60 \mathrm{~m}$; the toe is near the top of an ancient headscarp associated with the SDL. As the 2017 USDL moved, the toe, because it was near the top of the ancient headscarp, became oversteepened and unstable; as a result, it spawned several small, secondary, catastrophic failures in late January and February 2017 (figs. 2, 3 [on map sheet]; see also, fig. 8). This process likely will continue if landslide motion resumes.

Most movement of the 2017 USDL occurred between January 10 and January 27, 2017. Our GPS surveys were made after much of the landslide movement had already occurred; therefore, they did not capture the total amount of horizontal slip. Analysis of pre- and postlandslide satellite imagery indicated that displacements ranged from 4 to $6 \mathrm{~m}$. Furthermore, Carey and others (2017), using photogrammetric techniques, estimated a maximum of 5.4 $m$ of horizontal slip near the center of the landslide mass. Between January 28 and February 23, 2017, using RTK GPS, we measured minor horizontal landslide motion that was to the west-southwest, roughly parallel to the dip direction of the underlying bedrock, as is shown by repeated RTK GPS measurements of seven monuments within the 2017 USDL

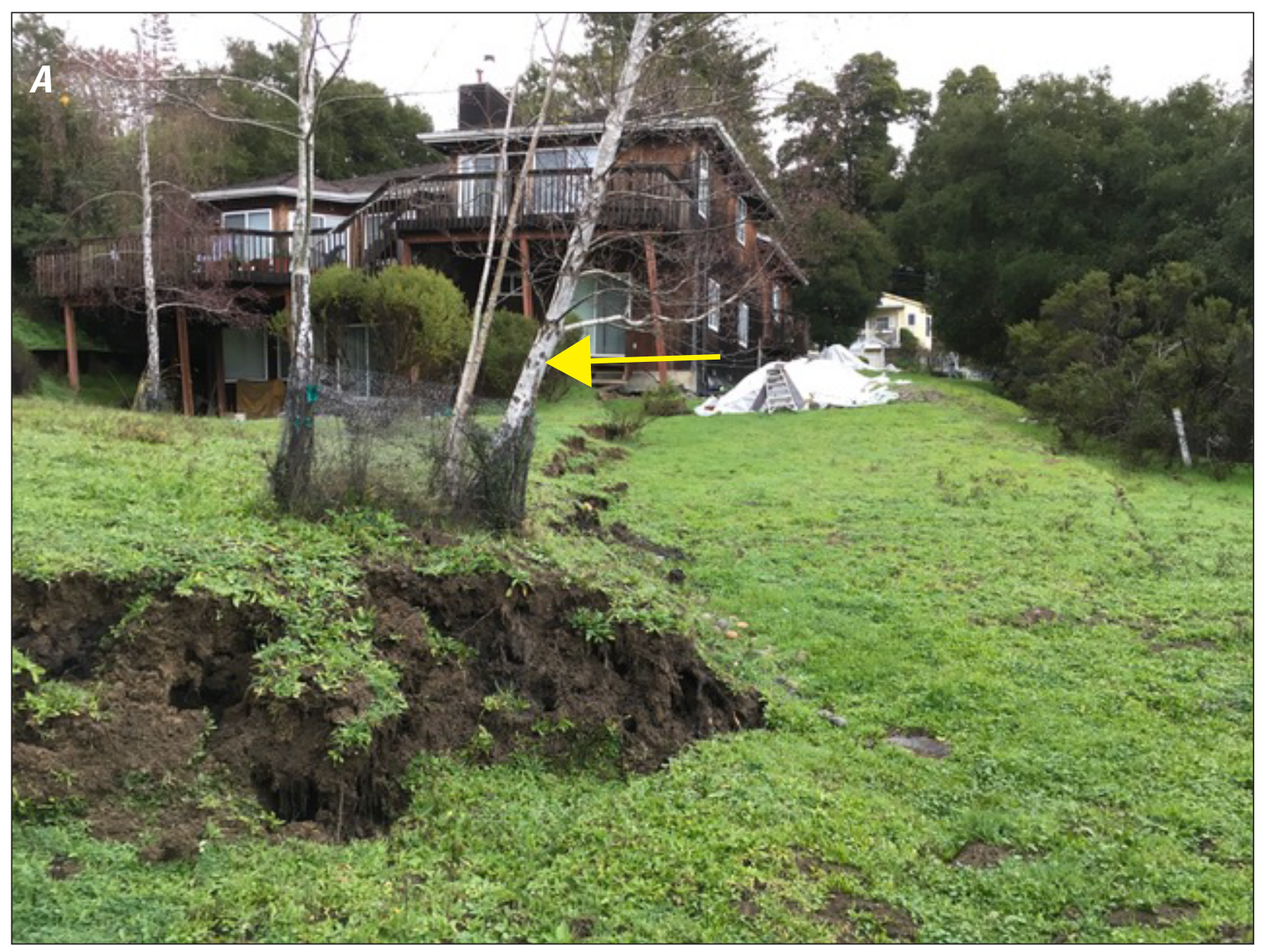

Figure 6. Photographs to east taken in backyard of home at 345 Scenic Drive (structure \#3 on fig. 3 [on map sheet]), showing development of graben along right flank of 2017 upper Scenic Drive landslide (USDL). Yellow arrow points to same tree in all three photographs. Photographs by Carol Prentice. A, Photograph taken on January 11, 2017, showing early movement of 2017 USDL. $B$, Photograph taken on January 16, 2017, showing further movement and graben development of 2017 USDL. C, Photograph taken on January 24, 2017, showing pond that accumulated in well-developed landslide graben. 

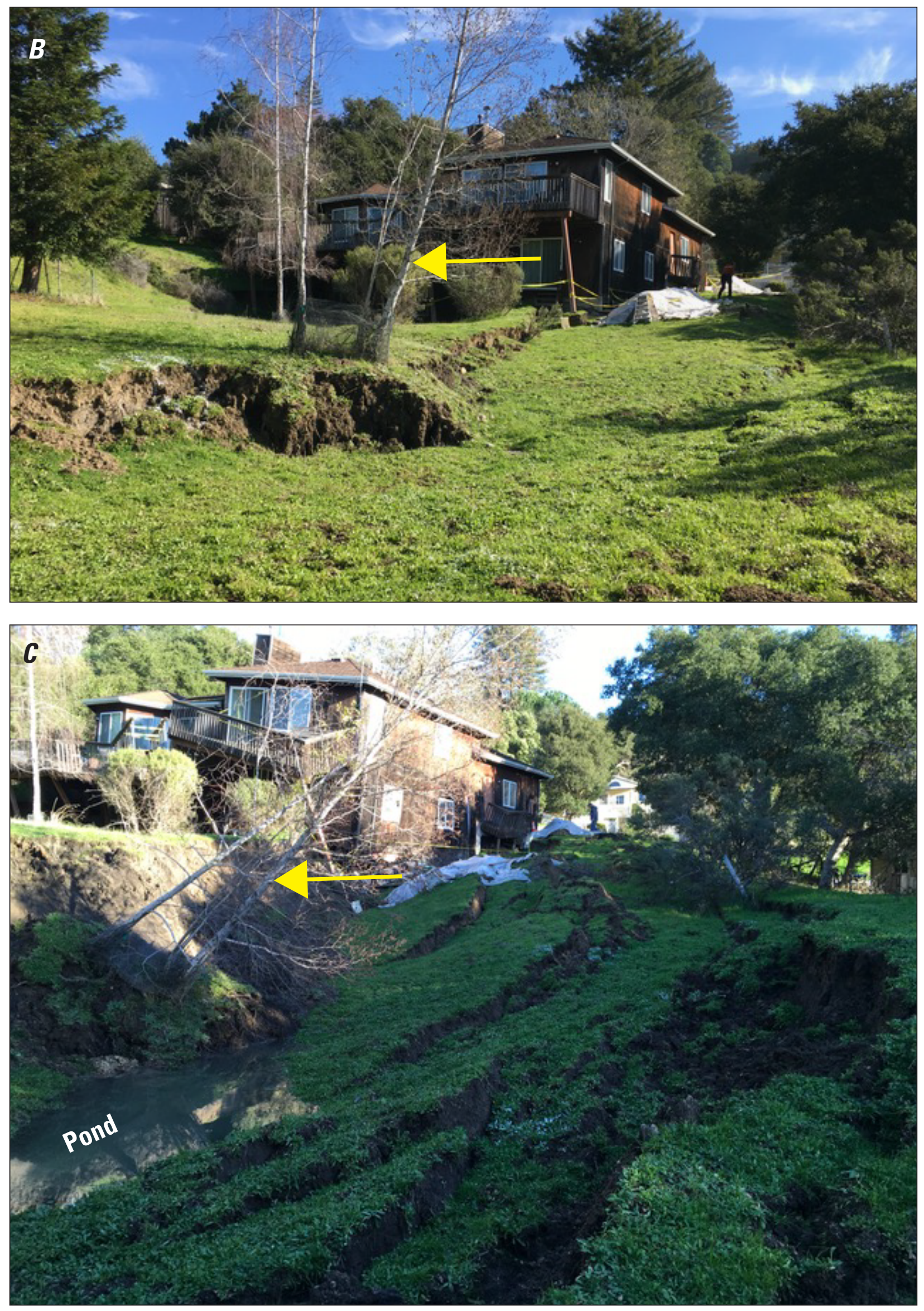

Figure 6.-Continued 

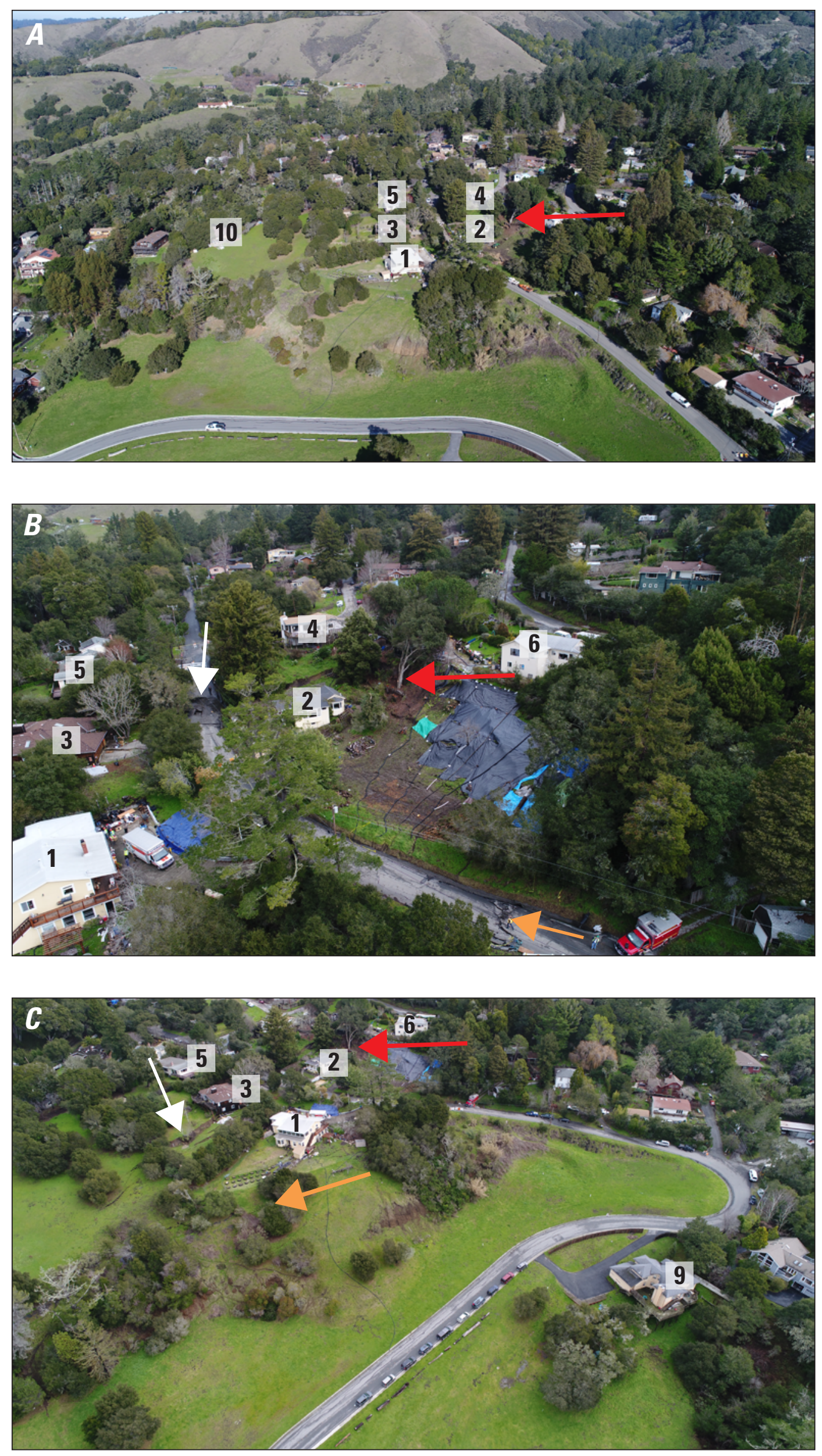

Figure 7. Oblique aerial

photographs of Scenic Drive area, showing features of 2017 upper Scenic Drive landslide (USDL). See figure 3 (on map sheet) for locations of numbered structures. In all three photographs, red arrow points to same oak tree below headscarp of 2017 USDL (also shown in figures $8 A, 9 B$, and 9D). Photographs by Ari Delay, La Honda Fire Brigade. A, Photograph to northeast, taken on January 17, 2017, showing overview of 2017 USDL. $B$, Photograph to northeast, taken on January 21, 2017.

White arrow points to right flank (northern margin) of 2017 USDL where it crosses Scenic Drive (also depicted in fig. 5); note white barricade across road above right flank (just above white arrow), which also is visible in figures $5 B$, $9 B$, and $9 D$. Orange arrow points to left flank (southern margin) of 2017 USDL where it crosses Scenic Drive. Note blue and black tarps set out by homeowner over parts of landslide to prevent infiltration of rainwater. $C$, Photograph to east, taken on January 21, 2017. White arrow points to graben and pond (also depicted in fig. $6 C$ ) that formed along right flank of 2017 USDL behind structure \#3. Orange arrow points to landslide toe (see fig. 8) in its early stage of development. 

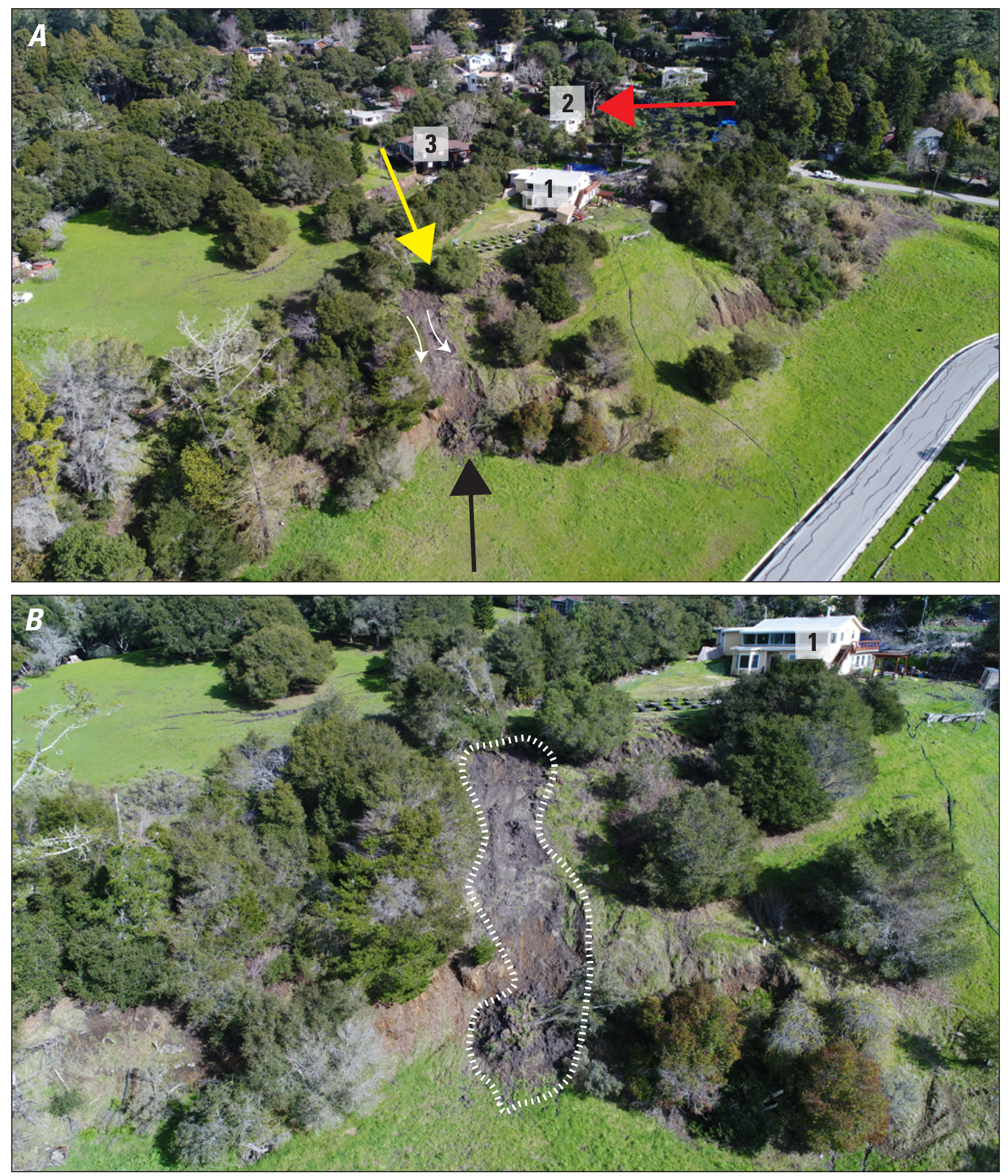

Figure 8. Oblique aerial photographs to northeast, showing localized failure along toe of 2017 upper Scenic Drive landslide (USDL). Photographs taken on January 25, 2017, by Ari Delay, La Honda Fire Brigade. See figure 3 (on map sheet) for locations of numbered structures. $A$, Overview of 2017 USDL. Yellow arrow points to source of toe collapse; black arrow points to deposit at base of Scenic Drive landslide headscarp. Paired curved white arrows indicate direction of downslope movement. Red arrow points to same oak tree (below headscarp of landslide) that is shown in figures $7 A-C, 9 B$, and $9 D$. $B$, Closer view of localized failure along toe of 2017 USDL. White hachures outline toe collapse.

(figs. 10, 11; see also, table 1). Total horizontal movement between January 28 and February 23 was at least $5 \mathrm{~cm}$ (station BLUE15) and no more than $28 \mathrm{~cm}$ (BLUE13). No measurable landslide motion occurred after February 23, and none of the monuments outside of the current 2017 USDL boundaries moved within the limits of our measurement error (horizontal, about $2 \mathrm{~cm}$; vertical, $3 \mathrm{~cm}$ ).

Differencing the 2017 TLS data with 2005 airbornelidar data provides an estimate of total vertical elevation changes within the 2017 USDL (fig. 13A). The part of the 

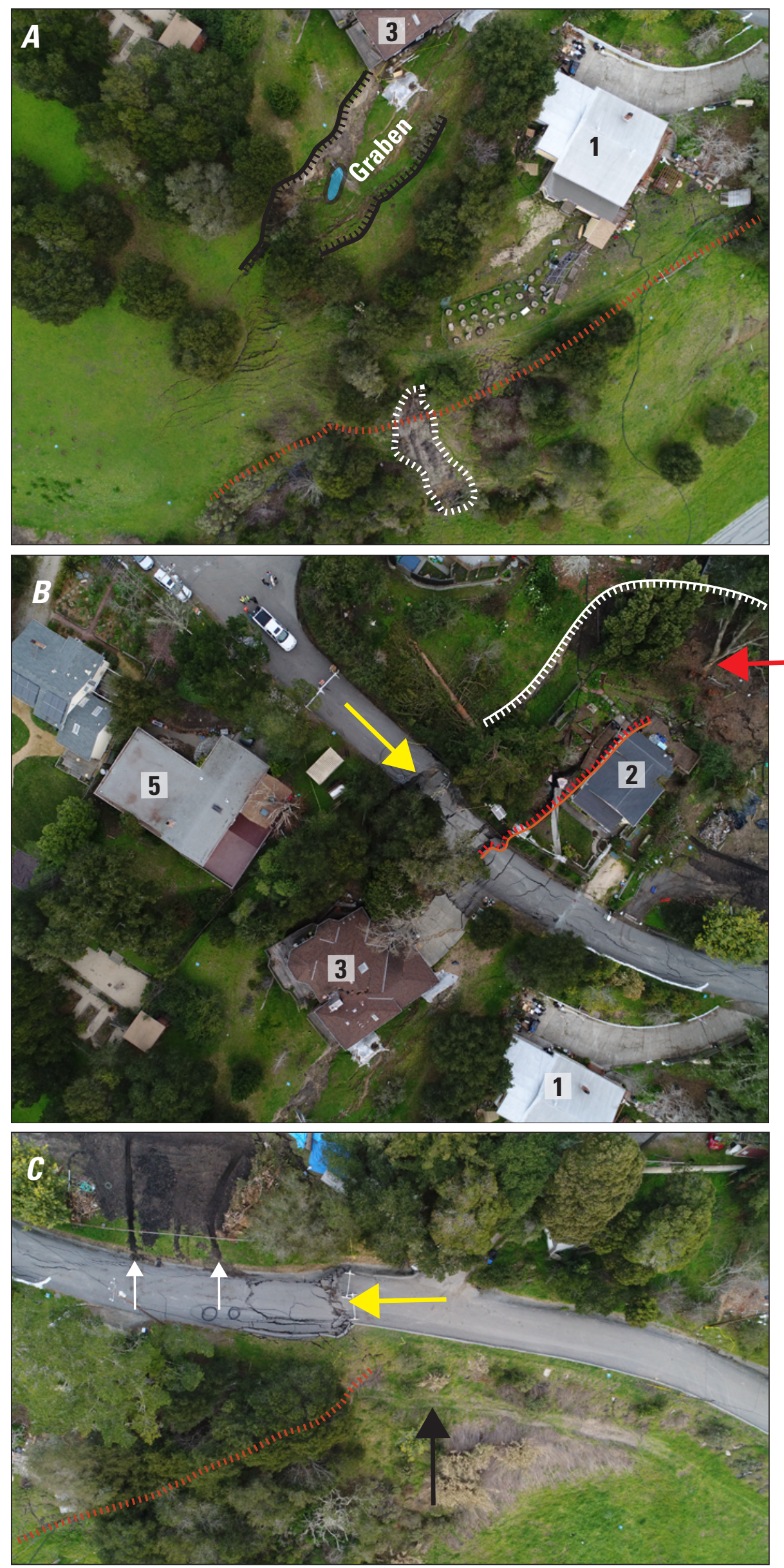

Figure 9. Oblique aerial photographs of upper Scenic Drive area, showing features of 2017 upper Scenic Drive landslide (USDL). Photographs taken on January 31, 2017, by Ari Delay, La Honda Fire Brigade. See figure 3 (on map sheet) for locations of numbered structures. Red arrows in $B$ and $D$ point to same oak tree (below headscarp of USDL) that is shown in figures $7 A-C$ and $8 A$. $A$, Black hachured lines mark boundaries of graben developed along right flank of 2017 USDL behind structure \#3; hachures point into graben. Blue shading highlights pond that formed in graben. White hachures outline area of collapse due to oversteepening of landslide toe (also shown in figures $8 B$ and $9 D$ ); red hachures mark base of landslide toe. $B$, White hachured line marks headscarp of 2017 USDL; hachures point into landslide. Yellow arrow points to where right flank of 2017 USDL crosses Scenic Drive (also shown in figures $5 B$ and $7 B$; note white barricade across road above right flank).

Red hachured line marks uphill-facing scarp that forms south boundary of graben; hachures point upscarp. $C$, Yellow arrow points to left flank (southern margin) of 2017 USDL where it crosses Scenic Drive. Smaller white arrows point to channels that were excavated to help drain surface water within landslide mass. Red hachures mark approximate location of landslide toe. Black arrow points to approximate location of northernmost tie-back anchor installed as part of 2011 project to stabilize previous Scenic Drive landslides. $D$, White arrow points to channel that was excavated to help drain surface water in graben behind structure \#3. Red hachures mark approximate location of landslide toe. White hachures outline locations of debris flows due to local collapse of oversteepened toe (also shown in figures $8 B$ and $9 A$ ). Black arrow points to headscarp of previous $(2005,2006)$ Scenic Drive landslides. 
Figure 9.-Continued
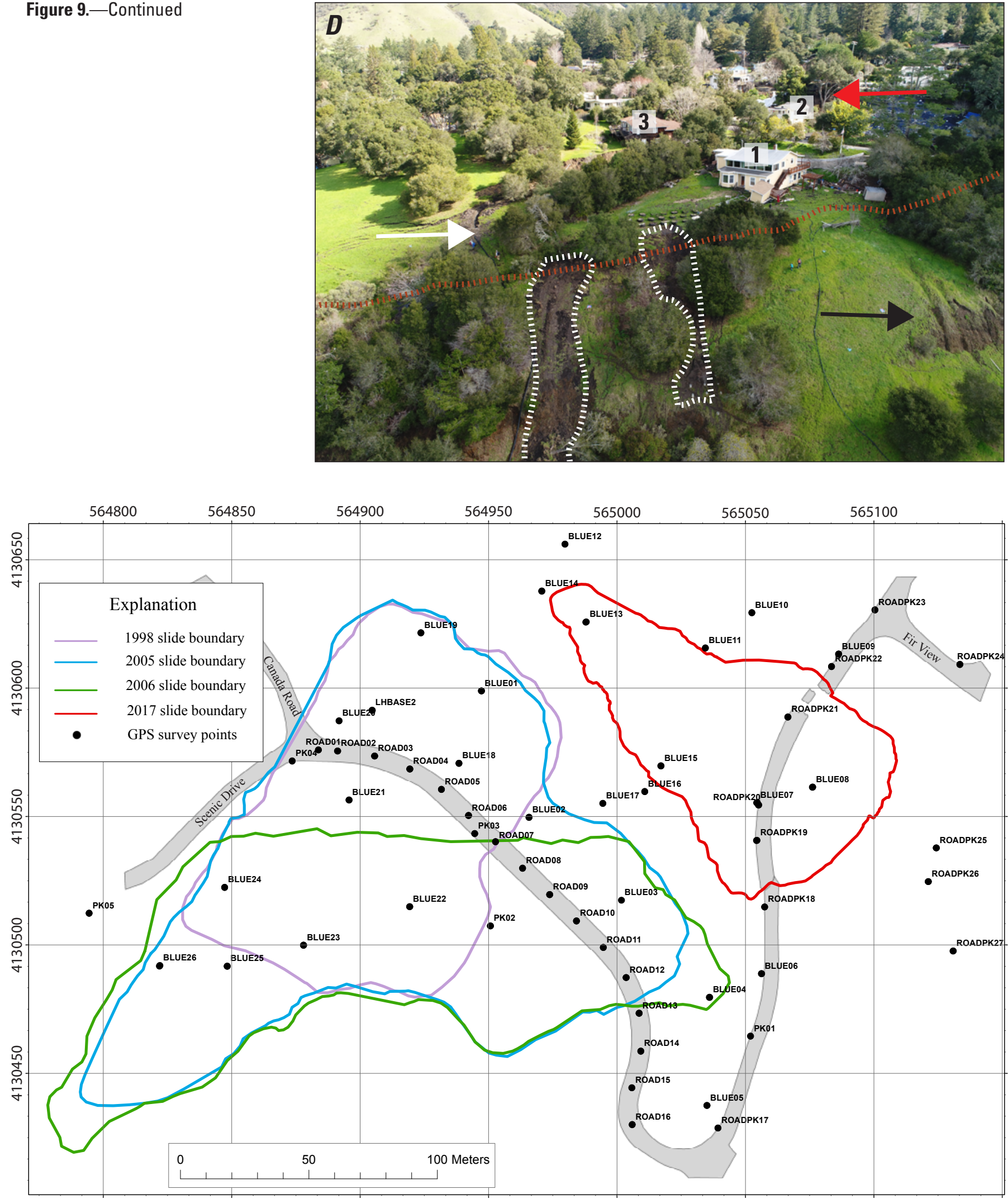

Figure 10. Schematic map showing boundaries of previous $(1998,2005,2006)$ Scenic Drive landslides, compared to that of 2017 upper Scenic Drive landslide (USDL; see fig. 1 for location). USDL, which is located above headscarps of previous Scenic Drive landslides, encompasses about 8,000 $\mathrm{m}^{2}$. Black dots indicate locations of 58 survey points and one local base station (labeled LHBASE2) used to monitor landslide activity: points labeled PK0105 are survey nails embedded in Scenic Drive roadway used for 2016 and 2017 real-time kinematic global positioning system and terrestrial laser scanner surveys; points labeled ROADPK17-27, survey nails placed in pavement on January 27, 2018, to monitor ongoing 2017 landslide activity; points labeled ROAD01-12, reflective lane markers along Scenic Drive; points labeled BLUE05-17, other survey markers placed throughout study area. 
landslide that is adjacent to the headscarp and within the graben behind 345 Scenic Drive subsided between 2 and 4 $\mathrm{m}$. Most of the remaining landslide uplifted from 0.5 to $2 \mathrm{~m}$, with a few areas uplifting 2 to $4 \mathrm{~m}$. Differencing the 2016 and 2017 TLS scans shows that the SDL remained stable, in contrast to the part of the 2017 USDL that is within the overlap area of the two TLS scans, which uplifted (fig. 13B).

\section{Rainfall and Landslide Activity}

Heavy rainfall during the winter of 2016-17 contributed to conditions that caused slope failure along the 2017 USDL. Historical landslides have also been associated with above average rainfall year totals (see Jayko and others, 1998; Wells and others, 2006). Rainfall began in October 2016

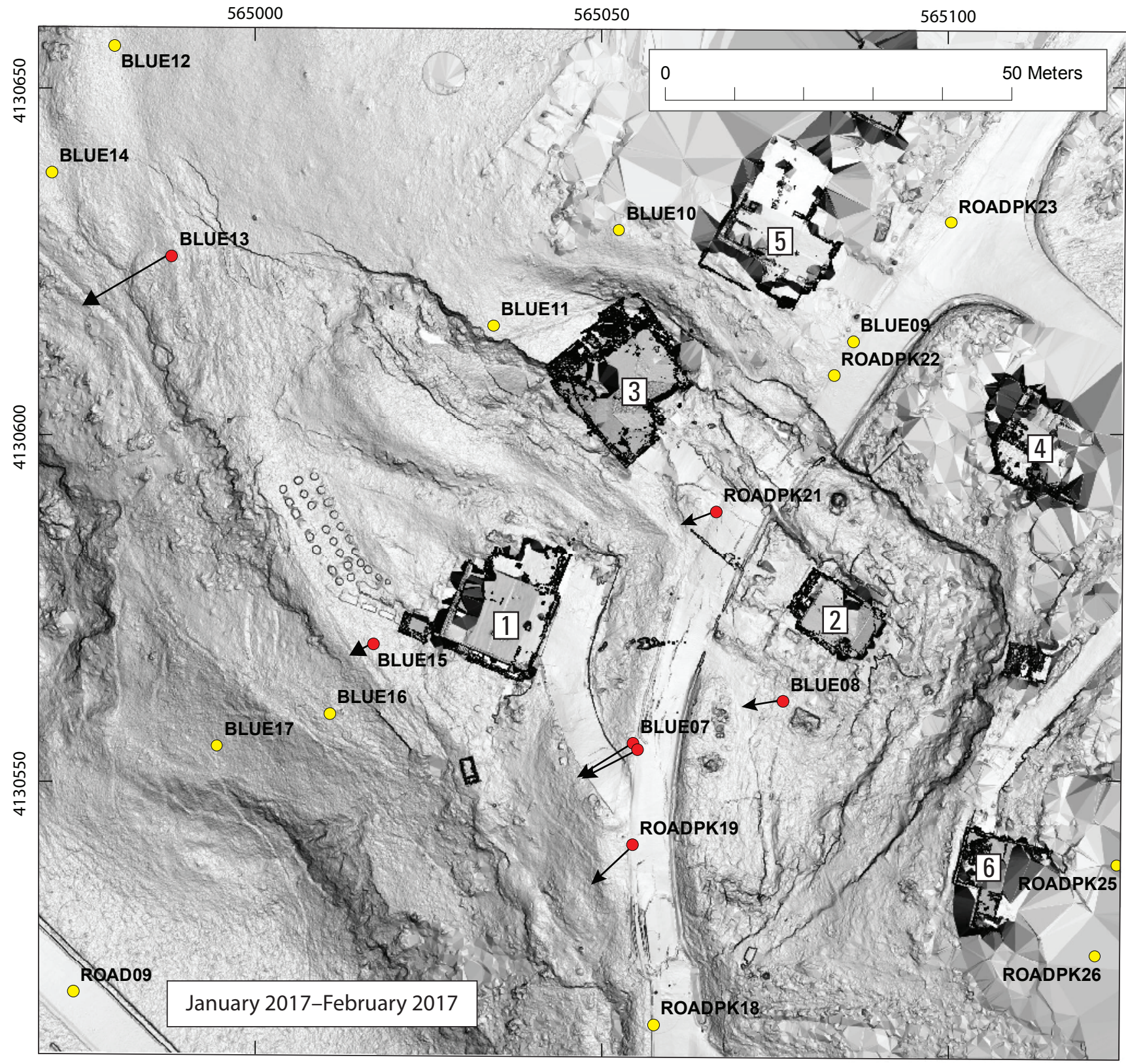

Figure 11. Slope-shade map of 2017 upper Scenic Drive landslide (USDL), showing real-time kinematic global positioning system and terrestrial laser scanner survey points (red dots, points within 2017 USDL; yellow dots, points outside of 2017 USDL) used for repeat surveys. Arrows on red dots are horizontal displacement vectors that indicate magnitude (distance relative to 10-cm arrow shown in lower right corner) and direction of movement from January 27-February 23, 2017; see table 1 for values of magnitude and directions of displacement. Yellow dots depict survey points that showed no displacement (within error of surveys). See figure 3 (on map sheet) for locations of numbered structures. 
Table 1. Horizontal and vertical displacement values and displacement azimuths for seven informally designated monuments (red dots in fig. 11) within the 2017 upper Scenic Drive landslide that occurred between January 27 and February 23, 2017.

[See figures 10, 11 for locations. Abbreviation: cm, centimeter(s)]

\begin{tabular}{lccc}
\hline \multicolumn{1}{c}{ Station no. } & Displacement distance, January 27-February 23 (cm) & Displacement azimuth \\
\cline { 2 - 3 } & Horizontal & Vertical & (degrees) \\
\hline ROADPK19 & 14 & 7 & 220 \\
ROADPK20 & 16 & 3 & 241 \\
ROADPK21 & 9 & 1 & 250 \\
BLUE07 & 17 & 3 & 231 \\
BLUE08 & 10 & 2 & 260 \\
BLUE13 & 28 & 1 & 243 \\
BLUE15 & 5 & 5 & 237 \\
\hline
\end{tabular}

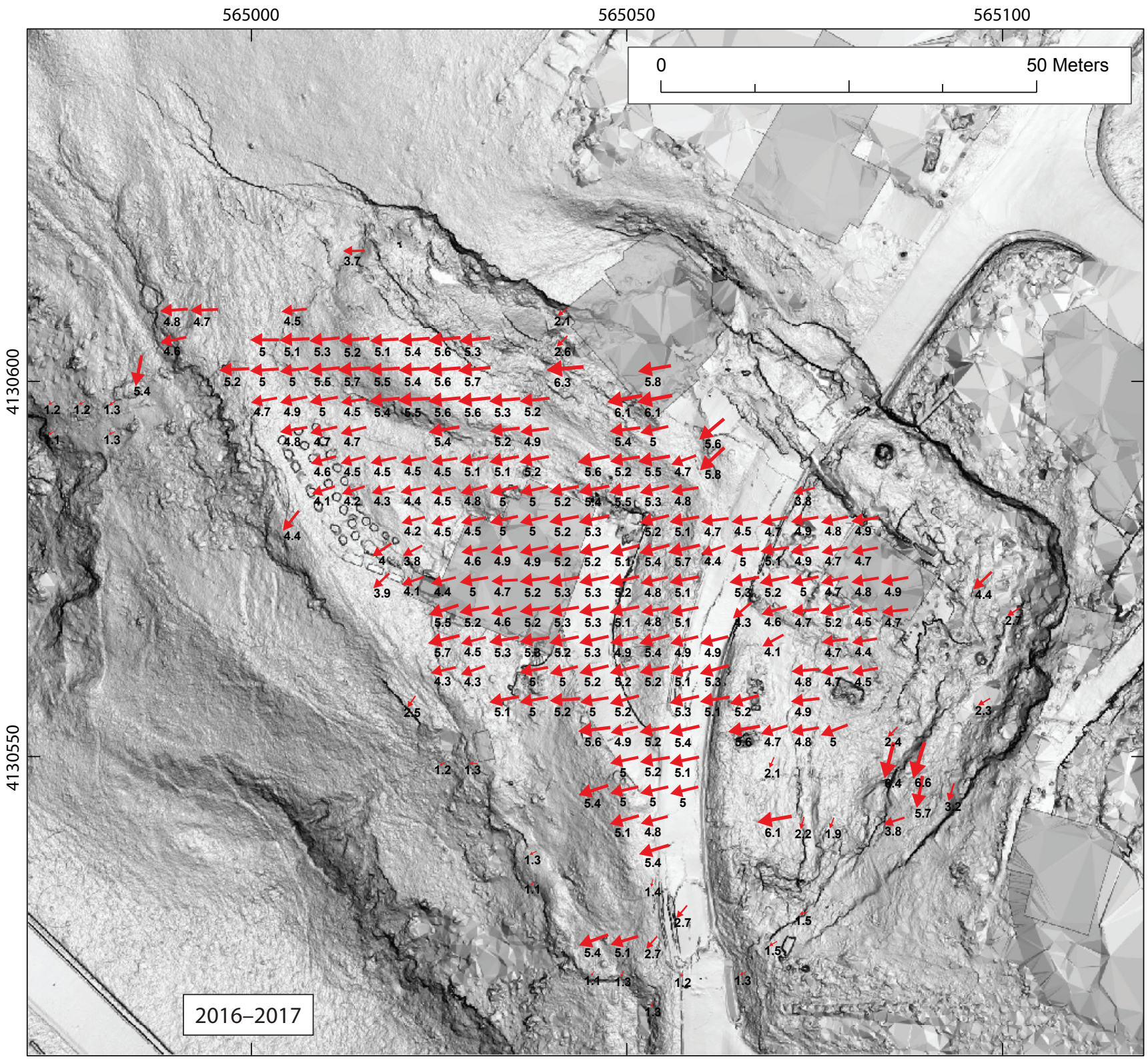

Figure 12. Shaded-relief map of 2017 upper Scenic Drive landslide (USDL), showing magnitudes (distance values, in meters) and directions (red arrows) of total horizontal displacement of 2017 USDL between 2016 and 2017, as measured by optical image correlation (see Leprince and others, 2007). Size of each arrow is scaled to distance value labeled below arrow. Displacements of less than 1 meter are not shown. 


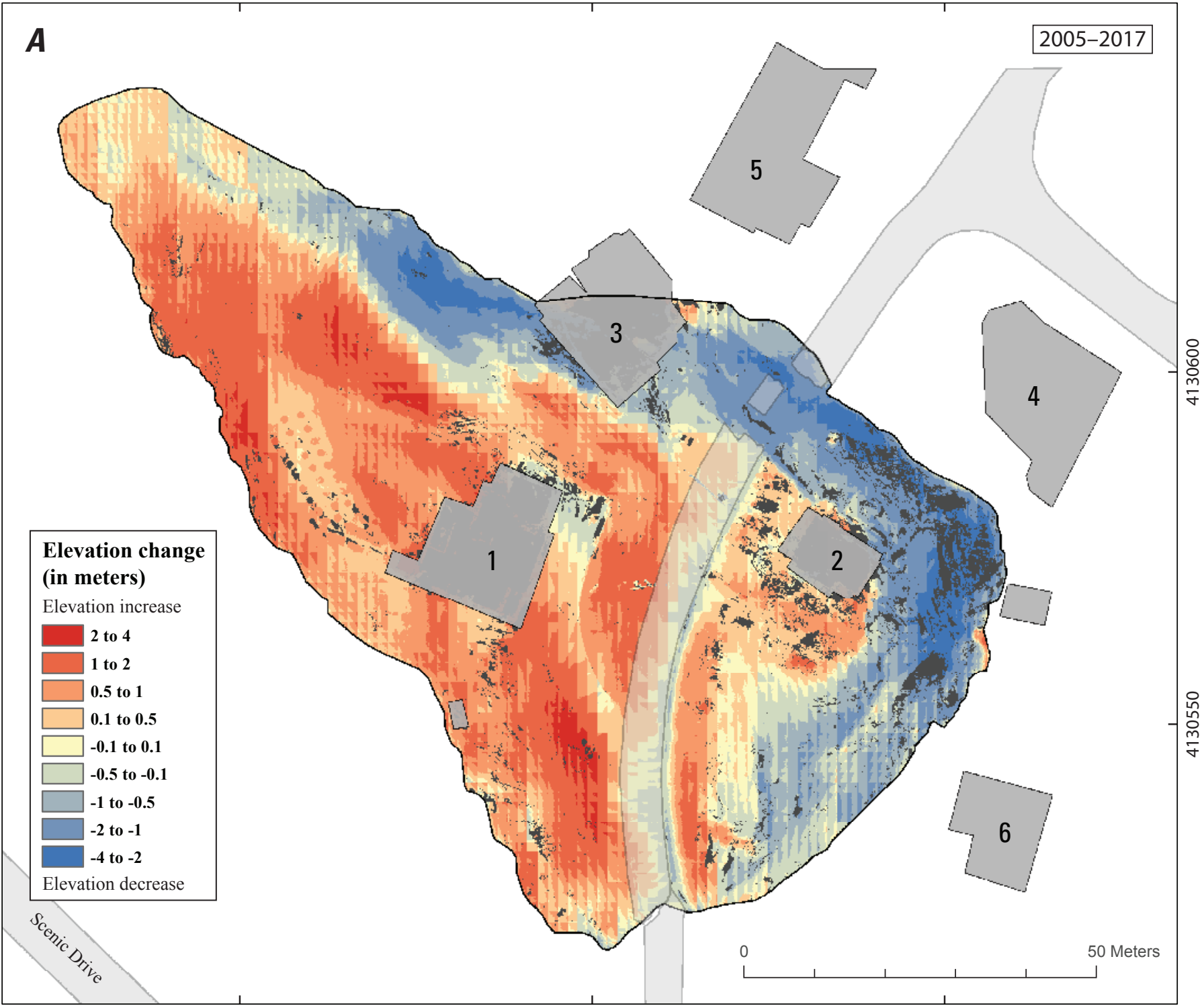

Figure 13. Maps showing changes in elevation within 2017 upper Scenic Drive landslide (USDL) and in surrounding area. Lighter gray areas are roads; numbered darker gray polygons are footprints of structures (see figure 3 [on map sheet] for locations). $A$, Changes in elevation within 2017 USDL between 2005 and 2017, as determined from terrestrial laser scanner (TLS) and airborne lidar (ALS) surveys. Elevation changes are calculated at $5-\mathrm{cm}$ resolution; jagged color pattern is due to resolution difference between TLS and ALS surveys. Data types and sources: 2005 data, 1.4-m-resolution ALS, acquired from San Mateo County; 2017 data, 5-cm-resolution TLS, from Pickering and others (2018). $B$ (on facing page), Changes in elevation within 2017 USDL and in surrounding area between 2016 and 2017, as determined from repeat TLS surveys. Map shows stability of repaired Scenic Drive landslide area, which moved in 1998, 2005 and 2006, as well as positive elevation changes in parts of 2017 USDL. Note that most of 2017 USDL area does not show elevation change because it was not surveyed in 2016; area where overlap between 2016 and 2017 TLS surveys exists is primarily near toe of 2017 USDL. Also note that minor elevation changes (pale-orange shading, 0.1-0.5 m) on either side of Scenic Drive do not indicate actual changes in elevation but, rather, are data-collection artifacts caused by inability of 2017 survey to penetrate tall grass.

and continued through December when several storms contributed $159 \mathrm{~mm}$ of rainfall, likely leading to an elevated water table (fig. 15). Long-term rainfall-year records show a precipitation average of $715 \mathrm{~mm} /$ year for the area, which had been under drought conditions during the previous few years (fig. 16). La Honda received $516 \mathrm{~mm}$ of rainfall prior to the landslide movement that occurred on January 10,2017 , and a total of $1,201 \mathrm{~mm}$ of rainfall for the entire 2017 rainfall year. The landslide motion in January 2017 occurred in response to a series of closely spaced storms between January 7 and 10, which produced $121 \mathrm{~mm}$ of rainfall; a peak rainfall intensity of $5.6 \mathrm{~mm} / \mathrm{hr}$ occurred 


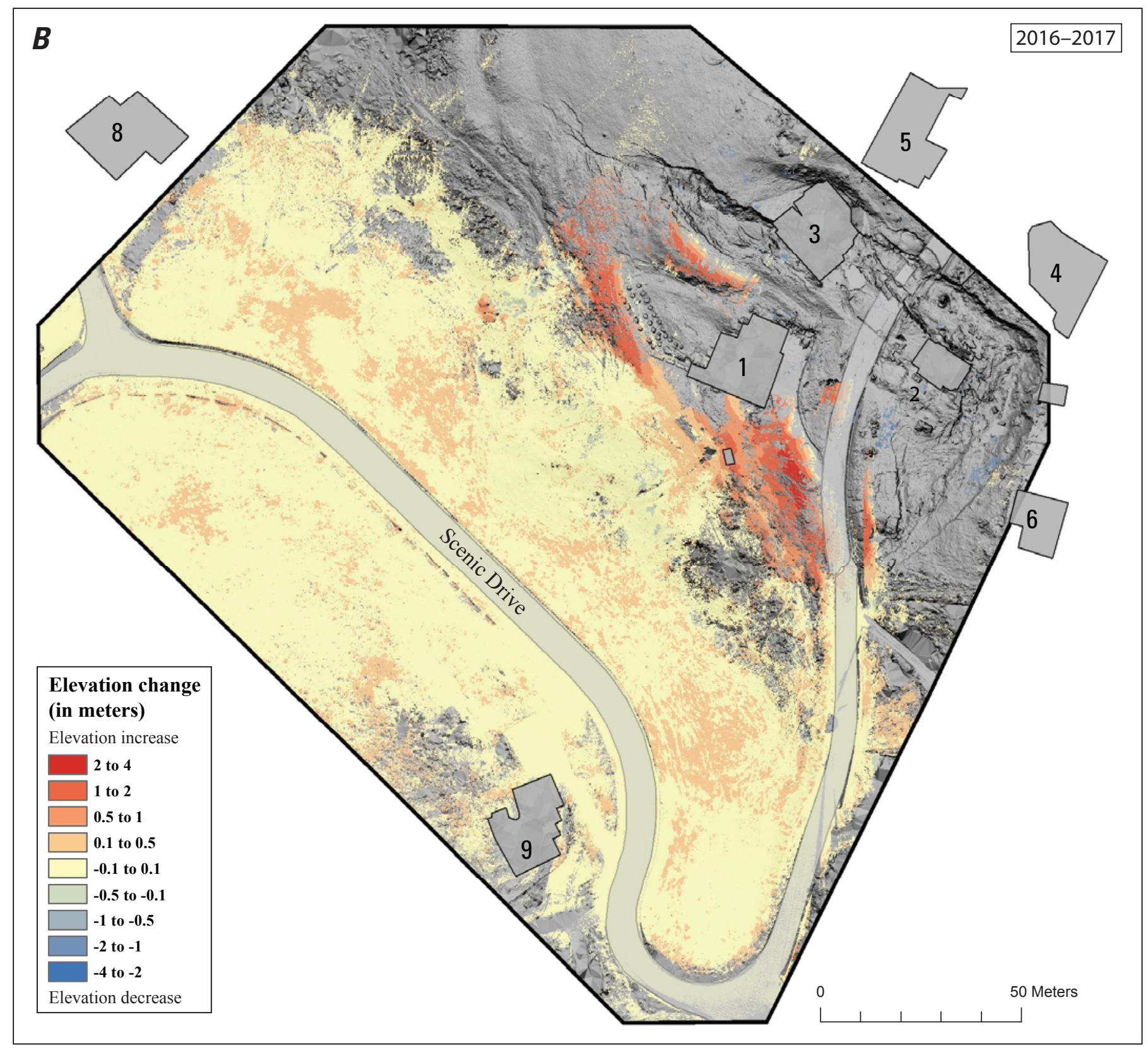

Figure 13.-Continued

overnight on January 8 into January 9 . The highest rainfall intensity, $11.7 \mathrm{~mm} / \mathrm{hr}$, occurred on January 18 , and most of the landslide motion occurred in response to this storm, as well as to the storms that occurred between January 20 and 23. Similar to past SDL episodes, the landslide responded to changes in rainfall rate, most of the movement occurring during or after large storms. Minor horizontal movement (as much as $28 \mathrm{~cm}$ in the western part of the landslide) occurred between January 28 and February 23. Between February 23 and June 28, coincident with decreasing rainfall, we measured no additional horizontal landslide motion. 


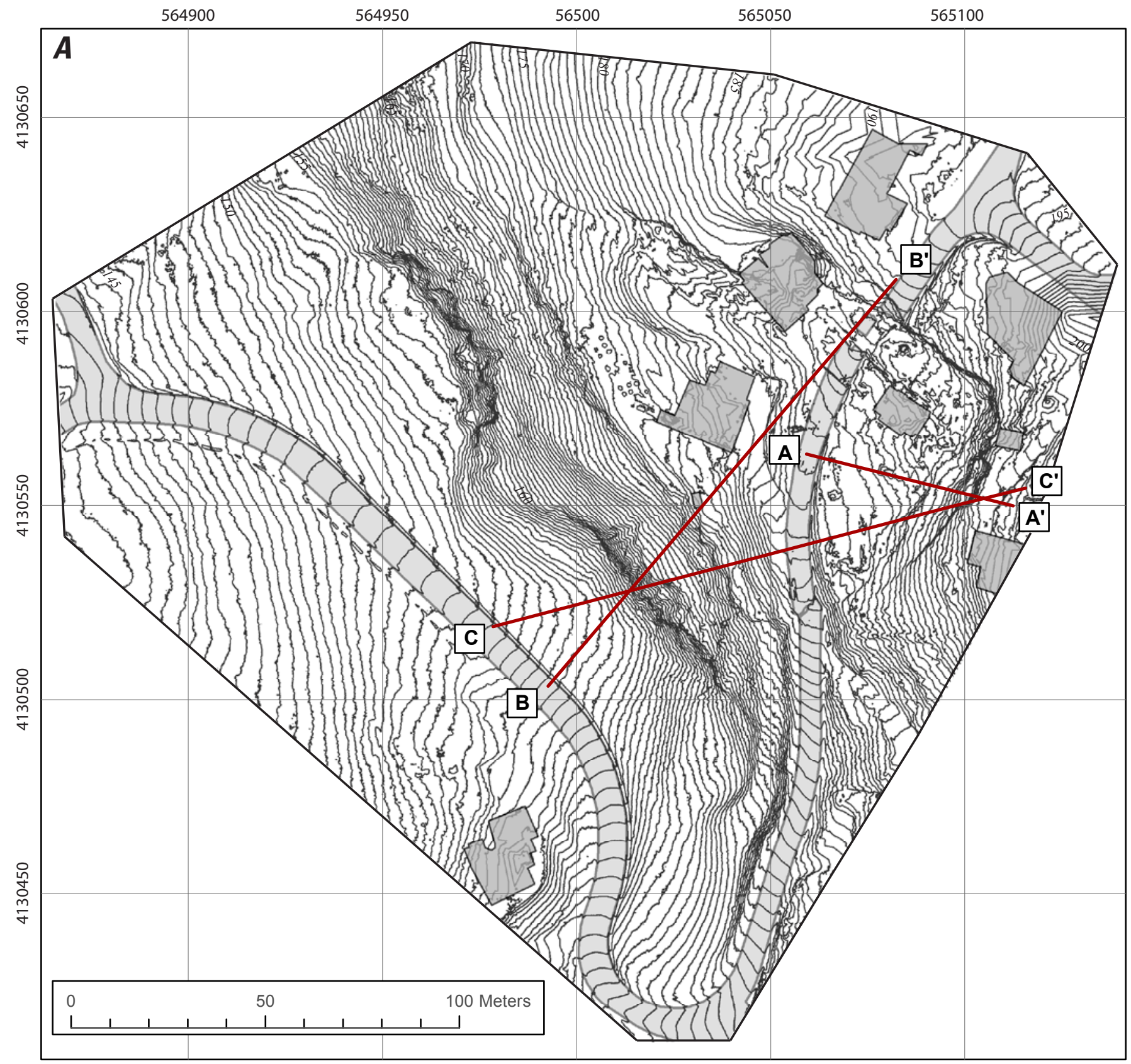

Figure 14. Contour map and topographic profiles of 2017 upper Scenic Drive landslide (USDL) and surrounding area. $A$, Contour map of same area as figure $13 B$, showing location of profiles in figure $14 B$ (on facing page). Lighter gray areas are roads; darker gray polygons are footprints of structures. Generated from $5-\mathrm{cm}$-resolution terrestrial laser scanner digital elevation model (NAD83, zone $10 \mathrm{~N})$, from Pickering and others (2018); contour interval, $0.5 \mathrm{~m}$. B, Topographic profiles illustrating prominent features of $2017 \mathrm{USDL}$ (see figure $14 A$ for locations of profiles). All three topographic profiles are scaled so that they have uniform vertical exaggeration.

\section{Limitations and Uncertainties}

Although the 2017 USDL stopped moving within the error of our surveys after February 23, 2017, further slip is possible in response to future winter storms unless remediation measures are undertaken. The suggestions and illustrations included in this report are intended to improve landslide awareness and preparedness; however, they do not guarantee the safety of an individual or structure. The contributors and sponsors of this report assume no liability for any injury, death, property damage, or other effects of the 2017 USDL. 
B
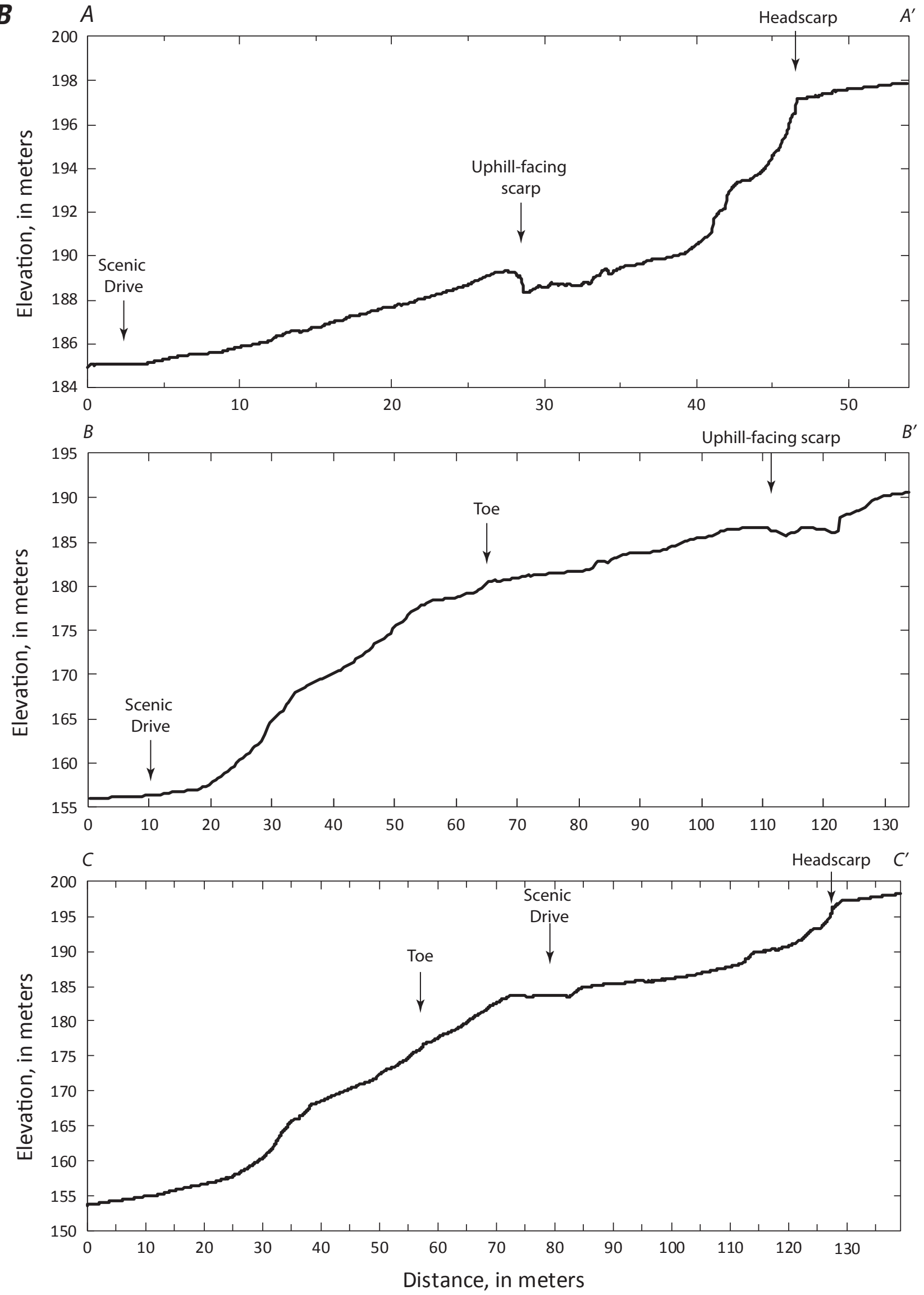

Figure 14.-Continued 


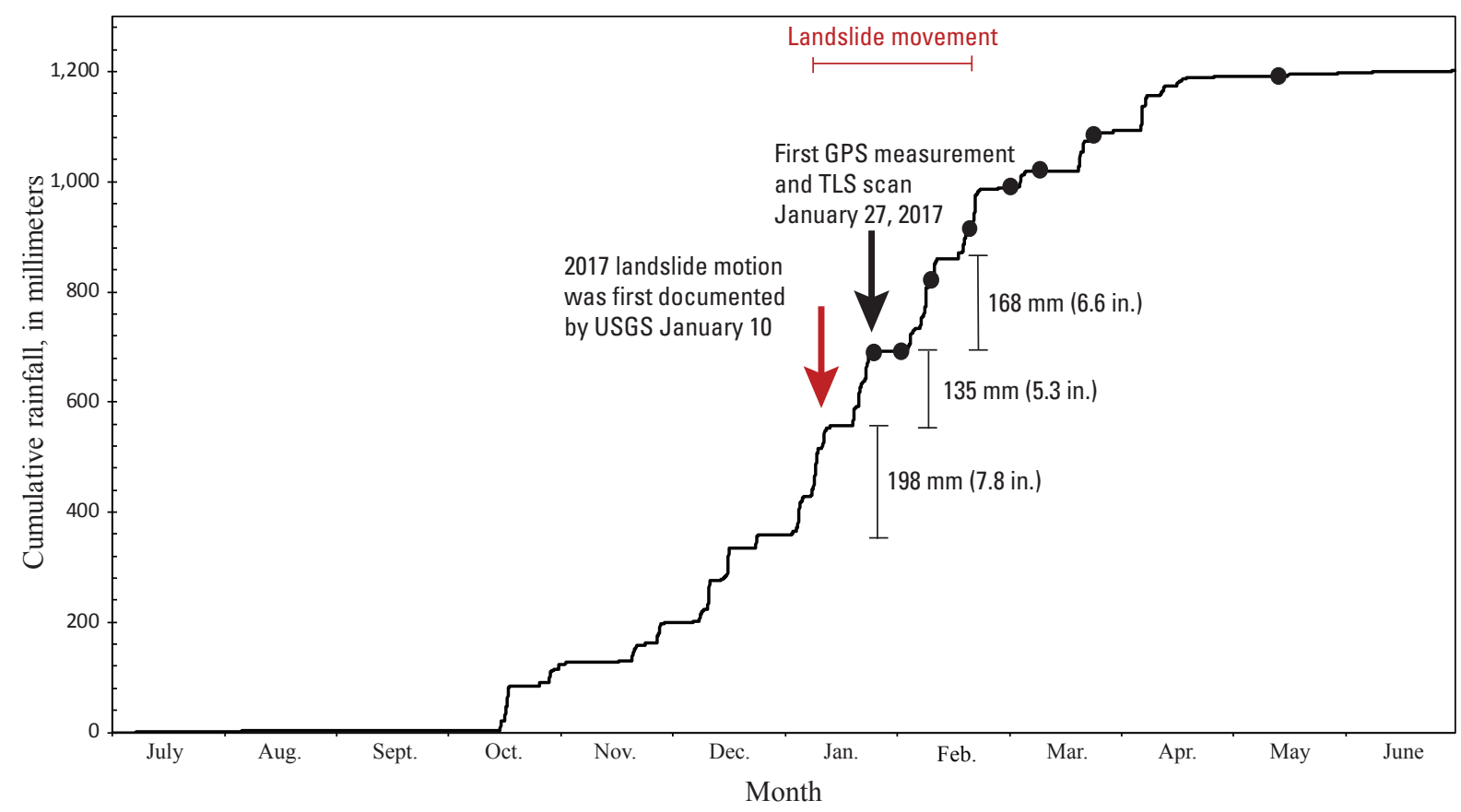

Figure 15. Plot showing cumulative rainfall for rainfall year 2016-2017, at La Honda, Calif. Rainfall data is from rain gauge LAH, located at Log Cabin Camp, about $1.9 \mathrm{~km}$ southwest of 2017 upper Scenic Drive landslide (USDL) (see fig. 1). Movement of 2017 USDL was first documented by USGS on January 10, 2017, after heavy rainfall from series of closely spaced storms that produced nearly $200 \mathrm{~mm}$ of rainfall in 10 days; most movement occurred between January 18 and 27, 2017, prior to terrestrial laser scanner (TLS) and real-time kinematic global positioning system (RTK GPS) surveys and coincident with several storms that added $135 \mathrm{~mm}$ of rainfall. After January 27, 2017, movement of 2017 USDL slowed significantly, and it had stopped by February 23, 2017. Black dots indicate dates of RTK GPS surveys.

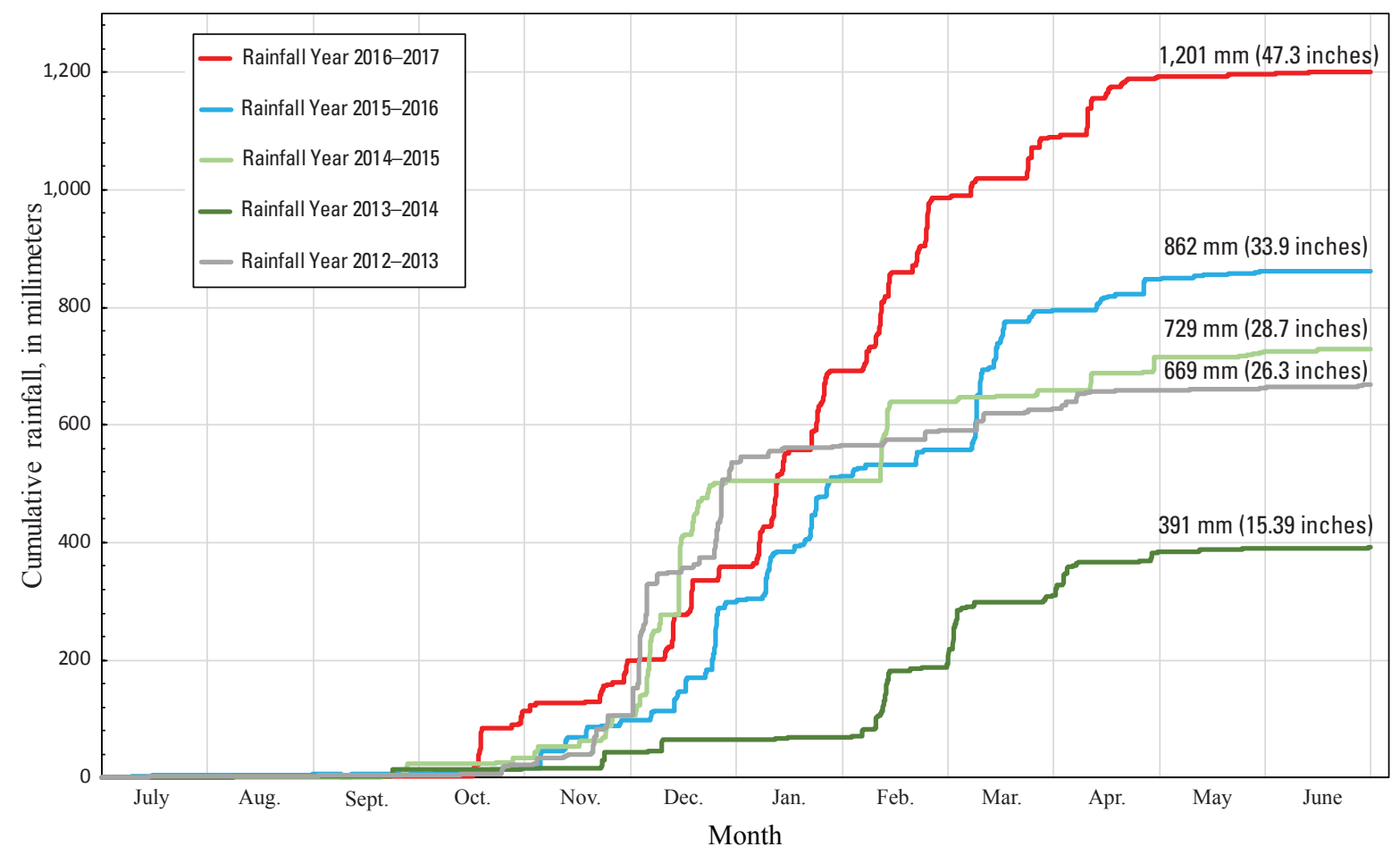

Figure 16. Plot showing cumulative rainfall for rainfall year 2016-2017 and four preceding rainfall years, at La Honda, Calif. Rainfall data is from rain gauge LAH, located about $1.9 \mathrm{~km}$ southwest of 2017 upper Scenic Drive landslide (see fig. 1 for location). Rainfall year 2016-2017 was among wettest on record, when a total of 1,201 mm of rainfall fell following several years of drought conditions. According to long-term $(20 \mathrm{yr}$ ) records, normal rainfall averages $715 \mathrm{~mm} / \mathrm{yr}$. Previous years of movement of Scenic Drive landslides (1998, 2005, and 2006) all received above-average rainfall $(1,017,850$, and $769 \mathrm{~mm} / \mathrm{yr}$, respectively). 


\section{Acknowledgments}

We thank the landowners of La Honda, especially Marty Bollman, Chuck and Sherry Johnson, Derek and Paula Krogh, Brent Nelson, Jim Reswick, Patrick Sheridan, and David and Carolyn Worthington, for providing access to their properties. Thanks to Chief Ari DeLay of the La Honda Volunteer Fire Department for the use of his aerial photographs and videos. Thanks for their field assistance go to University of California, Davis, student Jordan Carey; San Jose State University students Kirby Keifer, Colin Phillips, Alex Schmurakov, and Dennis Woo; and San Jose State University professor Kimberly Blisniuk.

\section{References Cited}

Brabb, E.E., and Pampeyan, E.H., 1972, Preliminary map of landslide deposits in San Mateo County, California: U.S. Geological Survey Miscellaneous Field Studies Map MF-344, scale 1:62,500.

Brabb, E.E., Graymer, R.W., and Jones, D.L., 1998, Geology of the onshore part of San Mateo County, California-A digital database: U.S. Geological Survey Open-File Report 98-137, 2 sheets, scale 1:62,500, https://pubs. usgs.gov/of/1998/of98-137/.

Buckley, J., and Reid, C.N., 2016, Limited geologic and geotechnical study, emergency landslide-related distress mitigation measures - 345 Scenic Drive, San Mateo County, California: Campbell, Calif., C2Earth, Inc., Document 16075C-01R1, 12 p.

Carey, J., Pickering, A.J., Prentice, C.S., Pinter, N., and DeLong, S.B., 2017, Analysis of landslide kinematics using multi-temporal UAV imagery, La Honda, California [abs.]: EOS, Transactions of the American Geophysical Union, AGU Fall Meeting, New Orleans, La., Abstract NH43A-0197.
Jayko, A.S., Rymer, M.J., Prentice, C.S., Wilson, R.C., and Wells, R.E., 1998, Scenic Drive landslide of JanuaryMarch 1998, La Honda, San Mateo County, California: U.S. Geological Survey Open-File Report 98-229, https://pubs.usgs.gov/of/1998/of98-229/.

Leprince, S., Barbot, S., Ayoub, F., and Avouac, J.P., 2007, Automatic and precise orthorectification, coregistration, and subpixel correlation of satellite images, application to ground deformation measurements: IEEE

Transactions on Geoscience and Remote Sensing, v. 45, no. 6, p. 1529-1558.

Pickering, A.J., DeLong, S.B., and Prentice, C.S., 2018, Terrestrial lidar data from the 2017 upper Scenic Drive landslide, La Honda, California-Classified point cloud and gridded elevation data from 2016-2017: U.S. Geological Survey data release, https://doi.org/10.5066/ F71Z43NV.

Upp, R.R., 1998, Geotechnical investigation-Landslide mitigation, Scenic Drive, San Mateo County, California: Upp Geotechnology Incorporated, Report to San Mateo County Environmental Services Agency.

Varnes, D.J., 1978, Slope movement types and processes, in Schuster, R.L., and Krizek, R.J., eds., LandslidesAnalysis and control: Washington, D.C., National Research Council, Transportation Research Board, Special Report No. 176, p. 11-33.

Wells, R.E., Rymer, M.J., Prentice, C.S., and Wheeler, K.L., 2005, Map showing features and displacements of the Scenic Drive landslide, La Honda, California, during the period March 31-May 7, 2005: U.S. Geological Survey Open-File Report 2005-1191, scale 1:400, https://pubs. usgs.gov/of/2005/1191/.

Wells, R.E., Rymer, M.J., Prentice, C.S., and Wheeler, K.L., 2006, Map showing features and displacements of the Scenic Drive landslide, La Honda, California, during the period March 31, 2005-November 5, 2006: U.S. Geological Survey Open-File Report 2006-1397, 2 sheets, scale 1:400, https://pubs.usgs.gov/of/2006/1397/. 